\title{
This special issue is dedicated to Professor Neil Burford
}

\author{
Special Editors \\ Paul J. Ragogna \\ Western University \\ London, Ontario \\ Charles L.B. Macdonald \\ University of Windsor \\ Windsor, Ontario
}

